Jurnal Akuntansi Indonesia, Vol. 9 No. 1 Januari 2020, Hal. 1 - 10

\title{
Analisis Efektivitas dan Efisiensi Anggaran Belanja
}

(Studi Empiris Pada Badan Kesatuan Bangsa dan Politik Kabupaten Sleman)

\author{
Afuan Fajrian Putra' \\ Novia Dhiniharitsa ${ }^{2}$ \\ Universitas Islam Indonesia \\ 'afuan.putra@uii.ac.id \\ 216212044@students.uii.ac.id
}

\begin{abstract}
This research is the result of an empirical study that shows the facts and explains about the properties that occur in the object under study. This study aims to analyze the effectiveness and efficiency of the budget. National Unity and Politics Agency of Sleman Regency. The results of this study indicate that the level of effectiveness of the expenditure budget into the category is quite effective. While the level of efficiency of the budget shows the efficient and very efficient categories. This research has implications for the National Unity Agency as a material for performance evaluation related to the process of preparing and absorbing the budget.
\end{abstract}

Keywords: Budgeting, effectiveness, efficiency, public sector

\section{ABSTRAK}

Penelitian ini merupakan hasil dari studi empiris yang menunjukkan fakta-fakta dan menjelaskan tentang sifat yang terjadi pada objek yang diteliti. Penelitian ini bertujuan untuk menganalisis efektivitas dan efisiensi anggaran belanja. Objek dari penelitian ini adalah Badan Kesatuan Bangsa dan Politik Kabupaten Sleman. Hasil dari penelitian ini menunjukkan bahwa tingkat efektivitas terhadap anggaran belanja masuk kedalam katagori cukup efektif. Sedangkan tingkat efisiensi terhadap anggaran belanja menunjukkan katagori efisien dan sangat efisien. Penelitian ini mempunyai implikasi kepada Badan Kesbangpol sebagai bahan evaluasi kinerja terkait dengan proses penyusunan dan penyerapan anggaran belanja.

Kata Kunci: Anggaran, Efektivitas, Efisiensi, Sektor Publik

\section{PENDAHULUAN}

Pada dewasa ini efektivitas dan efisiensi merupakan tuntutan yang harus dilakukan oleh setiap organisasi terutama organisasi yang tugas utamanya adalah melakukan pelayanan terhadap masyarakat (Monoarfa, 2012). Prinsip ini bisa dijadikan dasar dalam melihat kinerja dari masing-masing organisasi tersebut. Pengukuran kinerja perlu dilakukan agar pencapaian sasaran pada program yang telah direncanakan menjadi dapat diukur sehingga proses pengambilan keputusannya menjadi tepat (Harly dan Afriyenti, 2017). Pada level pemerintahan efektivitas dan efisiensi ini menjadi perhatian yang khusus terlebih lagi dengan adanya prinsip Good Corporate Government yang menuntut adanya keterbukaan dan tanggungjawab kepada stakeholders 
agar kinerja dari lembaga atau organisasi pemerintahan tersebut akan menjadi lebih tinggi (Tamasoleng, 2015). Anggaran belanja pada masing-masing lembaga atau organisasi pemerintah harus diukur dengan baik melalui prinsip efektivitas dan efisiensi organisasi publik. Pengukuran tersebut dapat menjadi kontrol bagi organisasi publk agar uang rakyat yang digunakan untuk roda pemerintahan lewat mekanisme anggaran bisa tersalur dan digunakan untuk hal-hal yang memang tepat sasaran (Syamsi, 2014).

Anggaran belanja merupakan cerminan dari sebuah kegiatan atau aktivitas dari organisasi publik itu sendiri yang dapat dinyatakan dalam satuan uang maupun satuan barang (Julita, 2011). Segala aktivitas yang sudah dan/atau sedang dan/atau akan datang diatur dalam anggaran belanja. Oleh karena itu agar anggaran belanja sesuai dengan aktivitas atau program yang direncanakan maka haruslah dilakukan proses perencanaan yang baik dan benar. Proses perencanaan anggaran belanja yang baik dan benar akan membawa pada keberhasilan penyerapan yang baik pula (Halim, 2014). Proses perencanaan anggaran belanja yang baik bisa dilakukan dengan membagi aktivitas atau program ke dalam rencana jangka pendek dan rencana jangka panjang. Pembagian tersebut akan memfokuskan anggaran pada sesuatu yang lebih penting untuk dilakukan atau diutamakan terlebih dahulu. Suatu program atau kegiatan tersebut haruslah melalui mekanisme perencanaan dan pembahasan terlebih dahulu sebelum masuk dalam proses penganggaran (Sudasri, 2014). Hal ini untuk menekan suatu pos anggaran yang programnya tidak penting.

Anggaran sangat berperan penting bagi sebuah organisasi dalam hal pencapaian tujuan (Julita, 2014). Anggaran menjadi kunci bagi program-program organisasi bisa berjalan dengan baik atau tidak. Oleh karena itu anggaran belanja yang sudah dibuat tersebut harus dapat diukur efektivitas dan efisiensinya agar kinerja dari suatu organisasi bisa dievaluasi. Proses pengukuran efektivitas dan efisiensi ini berfungsi untuk mengukur sejauh mana anggaran belanja organisasi bisa terserap untuk menjalankan program-program yang sudah direncanakan. Salah satu indikator pemerintahan yang baik adalah realisasi anggaran yang tercapai (Dwiyanto, 2005). Anggaran belanja dikatakan efektif jika anggaran belanja tersebut bisa terserap untuk menjalankan program-program atau kegiatan organisasi. Selain itu anggaran belanja dikatakan efisien jika output atau hasil yang didapatkan dari anggaran belanja tersebut bisa melebihi target dari program atau kegiatan organisasi tersebut (Mardiasmo, 2018).

Badan Kesatuan Bangsa dan Politik atau yang seterusnya disebut sebagai Badan Kasbangpol merupakan lembaga pelaksana urusan pemerintah dalam bidang kesatuan bangsa dan politik didalam negeri. Badan Kasbangpol ini sendiri berkedudukan dibawah dan bertanggung jawab kepada Bupati melalui Sekretaris Daerah. Kebijakan penggunaan semua dana diserahkan sepenuhnya kepada instansi tersebut. Sumber dana yang dimiliki oleh Badan Kasbangpol ini berasal dari APBD dan akan dipertanggungjawabkan melalui laporan realisasi anggaran. Laporan tersebut setidaknya memuat tentang prinsip-prinsip efektivitas dan efisiensi kinerja yang diukur melalui terserapnya anggaran yang dimiliki untuk mendanai program-program yang dimiliki oleh Badang Kasbangpol. Pertanggungjawaban atas pengelolaan kuangan Negara tersebut merupakan bagian bahwa organisasi pemerintahan harus bersifat akuntabel dan transparan atas kegiatan operasionalnya. Hal ini sesuai dengan Undang-undang Nomor 15 Tahun 2004 tentang Pemeriksaan atas Pengelolaan dan Tanggung Jawab Keuangan Negara.

2 
Berdasarkan penjelasan diatas maka dapat dirumuskan sebuah pertanyaan penelitian yaitu apakah anggaran belanja Badang Kasbangpol sudah efektif dan efisien sesuai dengan Keputusan Menteri Dalam Negeri Nomor 690.900-327 Tahun 1996. Berdasarkan pertanyataan penelitian tersebut maka tujuan dari penelitian ini adalah untuk menganalisis tingkat efektivitas dan efisiensi anggaran belanja pada Badan Kasbangpol.

\section{TINJAUAN LITERATUR DAN PENGEMBANGAN HIPOTESIS}

\section{Anggaran}

Salah satu cara dalam mengelola keuangan organisasi adalah dengan cara melakukan perencanaan dan penganggaran yang baik. Anggaran merupakan penyertaan estimasi kinerja yang sekiranya akan dicapai selama periode tertentu (bulan atau tahun) yang diterjemahkan dalam bentuk finansial (Mardiasmo, 2018). Rencana kerja yang dinyatakan secara kuantitatif tersebut harus dapat diukur dengan menggunakan satuan moneter dan standar ukutan lainnya yang serupa dalam jangka waktu tertentu (Mulyadi, 2016). Anggaran merupakan representasi dari suatu organisasi untuk mengalokasikan sumber daya yang dimiliki kedalam kebutuhan atau program yang dimiliki (Nordiawan dan Hertianti, 2010). Anggaran memiliki beberapa fungsi yang bisa digunakan sebagai alat perencanaan, alat pengendalian, alat kebijakan fiskal, alat politik, alat koordinasi dan komunikasi, alat penilaian kinerja, alat motivasi, dan alat penciptaan ruang publik (Mardiasmo, 2018). Anggaran tersebut nantinya akan dipertanggungjawabkan dalam bentuk laporan realisasi anggaran yang isinya mengandung unsur kegiatan pendapatan, kegiatan belanja, kegiatan transfer, dan kegiatan pembiayaan.

Berdasarkan Peraturan Menteri Dalam Negeri Nomor 13 Tahun 2006 Tentang Pedoman Pengelolaan Keuangan Daerah membagi anggaran belanja kedalam dua bagian yaitu anggaran belanja langsung dan anggaran belanja tidak langsung. Anggaran belanja langsung merupakan anggaran belanja yang memiliki hubungan secara langsung terhadap pelaksanaan program dan kegiatan suatu organisasi. Sedangkan anggaran belanja tidak langsung merupakan anggaran belanja yang tidak ada hubungannya secara langsung terhadap pelaksanaan program dan kegiatan suatu organisasi.

\section{Efektivitas dan Efisiensi Anggaran Sektor Publik}

Salah satu indikator dari pengukuran kinerja terhadap suatu program atau kegiatan adalah dengan mempertimbangkan sisi efektivitas dan efisiensi. Organisasi dikatakan efektif jika program-program atau kegiatan yang sudah dirancang dapat dijalankan sesuai dengan target yang sudah ditetapkan. Hal ini menunjukkan bahwa efektivitas selalu erat kaitannya dengan hasil atau output yang dicapai. Sedangkan organisasi dikatakan efisien jika program-program atau kegiatan yang sudah dirancang mampu untuk dilaksanakan dengan menggunakan input yang serendah-rendahnya. Mardiasmo (2018) menyebutkan bahwa efisiensi ini erat kaitannya dengan konsep produktifitas.

Efektivitas dapat diukur dengan cara membandingkan antara target anggaran belanja langsung dengan realisasi anggaran belanja langsung kemudian hasilnya dikalikan dengan 100\% (Mahsun, 2009). Berikut adalah rumus untuk menentukan efektivitas dari suatu anggaran belanja: 


$$
\text { Efektivitas }=\frac{\text { Realisasi belanja langsung }}{\text { Target belanja langsung }} \times 100 \%
$$

Berdasarkan Keputusan Menteri Dalam Negeri Nomor 690.900-327 Tahun 1996 Tentang Pedoman Penilaian Kinerja Keuangan bahwa anggaran belanja dapat dikatakan efektif jika memenuhi kriteria-kriteria di bawah ini:

Tabel 1: Kriteria Efektivitas

\begin{tabular}{lll}
\hline \multicolumn{2}{c}{ Prosentase } & Keterangan \\
\hline$>100 \%$ & Sangat Efektif \\
$90 \%-100 \%$ & Efektif \\
$80 \%-90 \%$ & Cukup Efektif \\
$60 \%-80 \%$ & Kurang Efektif \\
$<60 \%$ & Tidak Efektif \\
\hline
\end{tabular}

Sumber: Keputusan Menteri Dalam Negeri Nomor 690.900-327 Tahun 1996

Sedangkan efisiensi dapat diukur dengan cara membandingkan antara realisasi belanja langsung dengan realisasi anggaran belanja kemudian hasilnya dikalikan dengan 100\%. Berikut adalah rumus untuk menentukan efisiensi dari suatu anggaran belanja:

$$
\text { Efisiensi }=\frac{\text { Realisasi belanja langsung }}{\text { Realisasi anggaran belanja }} \times 100 \%
$$

Berdasarkan Keputusan Menteri Dalam Negeri Nomor 690.900-327 Tahun 1996 Tentang Pedoman Penilaian Kinerja Keuangan bahwa anggaran belanja dapat dikatakan efisien jika memenuhi kriteria-kriteria di Tabel 2.

Tabel 2: Kriteria Efisiensi

\begin{tabular}{ll}
\hline \multicolumn{1}{c}{ Prosentase } & Keterangan \\
\hline$>100 \%$ & Tidak Efisien \\
$90 \%-100 \%$ & Kurang Efisien \\
$80 \%-90 \%$ & Cukup Efisien \\
$60 \%-80 \%$ & Efisien \\
$<60 \%$ & Sangat Efisien \\
\hline
\end{tabular}

Sumber: Keputusan Menteri Dalam Negeri Nomor 690.900-327 Tahun 1996

\section{METODE PENELITIAN}

Penelitian ini merupakan penelitian deskriptif yang menunjukkan fakta-fakta dari data yang diambil pada suatu objek yang diteliti. Sugiyono (2015) menjelaskan bahwa penelitian deskriptif merupakan penelitian yang 
bertujuan untuk menilai variabel tanpa menghubungkan antara variabel yang lain. Oleh karena itu penelitian deskriptif biasanya bertujuan untuk mendeskripsikan dan menjelaskan sifat yang terjadi pada objek tersebut. Objek dari penelitian ini adalah Badan Kesatuan Bangsa dan Politik yang berada di Kabupaten Sleman. Data yang digunakan dalam penelitian ini adalah data kuantitatif, sedangkan sumber data dalam penelitian ini menggunakan data sekunder yang diambil dari Laporan Realisasi Anggaran pada Badan Kesatuan Bangsa dan Politik Kabupaten Sleman. Data tersebut dilakukan analisis dengan pendekatan efektivitas dan efisiensi sesuai rumus yang telah dibahas sebelumnya.

\section{HASIL DAN PEMBAHASAN}

\section{Target dan Realisasi Anggaran Belanja}

Badan Kesbangpol Kabupaten Sleman menggunakan laporan realisasi anggaran sebagai media pertanggungjawaban atas anggaran yang sudah dikelola. Laporan tersebut setidaknya memuat tentang target dan realisasi anggaran belanja baik untuk belanja yang bersifat langsung maupun tidak langsung. Penelitian ini menggunakan target dan realisasi anggaran belanja baik langsung maupun tidak langsung yang sudah berlangsung tiga tahun terakhir yaitu tahun 2016 sampai 2018. Tabel 3 memuat rincian tentang target dan realisasi anggaran belanja pada Badan Kesbangpol :

Tabel 3: Target dan Realisasi Anggaran Belanja Langsung

\begin{tabular}{lcc}
\hline Tahun & Target Anggaran (Rp) & Realisasi Anggaran (Rp) \\
\hline 2016 & 2.495 .523 .400 & 2.238 .037 .763 \\
\hline 2017 & 2.392 .602 .200 & 2.141 .303 .053 \\
\hline 2018 & 5.285 .809 .500 & 4.527 .984 .006 \\
\hline
\end{tabular}

Sumber: Data Diolah

Berdasarkan tabel 3 diatas menunjukkan bahwa realisasi anggaran belanja langsung terdiri dari belanja pegawai serta belanja barang dan jasa. Terlihat bahwa Badan Kesbangpol belum bisa memaksimalkan anggaran yang sudah ditetapkan kedalam target anggaran. Hal ini disebabkan karena beberapa program yang sudah direncanakan tidak dapat terealisasikah sehingga berakibat pada penyerapan anggaran belanja langsung yang tidak maksimal juga. Anggaran belanja langsung ini digunakan untuk keperluan belanja pegawai, belanja barang dan jasa, dll.

Tabel 4: Target dan Realisasi Anggaran Belanja Tidak Langsung

\begin{tabular}{lcc}
\hline Tahun & Target Anggaran (Rp) & Realisasi Anggaran (Rp) \\
\hline 2016 & 1.187 .457 .150 & 1.140 .130 .181 \\
\hline 2017 & 2.232 .900 .000 & 1.851 .133 .772 \\
\hline 2018 & 2.068 .446 .607 & 1.910 .745 .965 \\
\hline
\end{tabular}

Sumber: Data Diolah 
Sedangkan pada tabel 4 menunjukkan bahwa anggaran belanja tidak langsung di Badan Kesbangpol juga belum maksimal. Realisasi anggaran belanja tidak langsung di Badan Kesbangpol digunakan untuk keperluankeperluan seperti pembayaran gaji dan tunjungan bagi pegawai yang bekerja di Badan Kesbangpol tersebut.

\section{Pengukuran Efektivitas Anggaran}

Efektivitas merupakan salah satu indikator yang paling sering digunakan untuk mengukur tingkat keberhasilan suatu organisasi dalam menyerap anggaran. Efektivitas erat kaitannya dengan output atau suatu hasil yang telah dicapai. Organisasi dikatakan memiliki efektivitas yang bagus jika mampu mewujudkan atau merealisasikan sesuatu yang sudah dirancang diawal. Begitupula sebaliknya, organisasi dikatakan memiliki efektivitas yang rendah jika tidak dan/atau belum mampu mewujudkan atau merealisasikan sesuatu yang telah dirancang sebelumnya. Pengukuran tingkat efektivitas organisasi dalam menyerap suatu anggaran bisa dilakukan dengan cara membagi antara realisasi belanja dengan target belanja kemudian dikali dengan $100 \%$. Hasil dari perhitungan tersebut yang nantinya akan menentukan bahwa organisasi tersebut sudah efektif atau belum efektif dalam menyerap suatu anggaran.

Badan Kesbangpol membagi anggaran belanja ke dalam dua aspek yaitu anggaran belanja langsung dan anggaran belanja tidak langsung. Berikut adalah perhitungan efektivitas untuk anggaran belanja pada Badan Kesbangpol.

$$
\begin{aligned}
& \text { Tahun 2016 }=\frac{2.238 .037 .763}{2.495 .523 .400} \times 100 \%=89,68 \% \\
& \text { Tahun } 2017=\frac{2.141 .303 .053}{2.392 .602 .200} \times 100 \%=89,49 \% \\
& \text { Tahun } 2018=\frac{4.527 .984 .006}{5.285 .809 .500} \times 100 \%=85,66 \%
\end{aligned}
$$

Tabel 5: Perhitungan Efektivitas Anggaran Belanja

\begin{tabular}{ccccc}
\hline Tahun & $\begin{array}{c}\text { Realisasi Belanja } \\
\text { Langsung }(\mathrm{Rp})\end{array}$ & $\begin{array}{c}\text { Target Belanja } \\
\text { Langsung (Rp) }\end{array}$ & $\begin{array}{c}\text { Prosentase } \\
(\%)\end{array}$ & Kriteria \\
\hline 2016 & 2.238 .037 .763 & 2.495 .523 .400 & 89,68 & Cukup Efektif \\
\hline 2017 & 2.141 .303 .053 & 2.392 .602 .200 & 89,49 & Cukup Efektif \\
\hline 2018 & 4.527 .984 .006 & 5.285 .809 .500 & 85,66 & Cukup Efektif \\
\hline
\end{tabular}

Sumber: Data Diolah

Berdasarkan perhitungan dan Tabel 5 diatas maka dapat disimpulkan bahwa selama tiga tahun terakhir, yakni dari tahun 2016 sampai 2018 penyerapan anggaran pada Badan Kesbangpol masih belum maksimal. Penyerapan anggaran masih di kisaran kurang dari 90\% yang masuk kedalam katagori cukup efektif. Hal ini 
dikarenakan bahwa masih adanya program-program yang belum terlaksana padahal sudah dianggarkan yang menyebabkan anggaran tidak bisa terserap seluruhnya. Badan Kesbangpol belum bisa melakukan seluruhnya program-program yang sudah direncakan. Hal tersebut bisa disebabkan karena program tersebut merupakan program yang tidak tepat sasaran sehingga tidak jadi dilaksanakan atau bisa juga karena koordinasi dari setiap bidang yang menjalankan program tersebut tidak terkoordinasi sehingga pada saat usulan program dan menetapkan anggaran menjadi tidak selaras. Oleh karena itu koordinasi dari tiap bidang dalam suatu organisasi menjadi faktor kunci program-program bisa terlaksana dan terealisasi sehingga penyerapan anggarannya juga bisa maksimal.

\section{Pengukuran Efisiensi Anggaran}

Efisiensi juga merupakan salah satu indikator dalam mengukur keberhasilan organisasi dalam menyerap suatu anggaran. Efisiensi memiliki hubungan yang saling berkaitan dengan efektivitas. Faktor tersebut menjadikan kedua elemen yaitu efektivitas dan efisiensi menjadi salah satu tolak ukur dalam menilai kinerja suatu organisasi. Efisiensi erat kaitannya dengan produktifitas suatu organisasi. Organisasi dikatakan efisien jika output atau hasil dapat dicapai dengan menggunakan input yang serendah-rendahnya atau sekecil-kecilnya. Begitupula sebaliknya, organisasi dikatakan memiliki efisiensi yang rendah jika input yang kecil tersebut tidak bisa mencapai output atau hasil yang diinginkan. Selain itu, organisasi dikatakan efisien jika output atau hasil yang dicapai bisa melampaui atau melebihi target yang telah ditetapkan diawal dengan menggunakan input yang sama. Pengukuran tingkat efisiensi organisasi dalam menyerap suatu anggaran bisa dilakukan dengan cara membagi antara realisasi belanja langsung dengan total realisasi anggaran belanja kemudian dikali dengan $100 \%$. Hasil dari perhitungan tersebut yang nantinya akan menentukan bahwa organisasi tersebut sudah efisien atau belum efisien dalam menyerap suatu anggaran. Berikut adalah perhitungan efisiensi untuk anggaran belanja pada Badan Kesbangpol :

$$
\begin{aligned}
& \text { Tahun } 2016=\frac{2 \cdot 238.037 .763}{3.378 .167 .944} \times 100 \%=66,25 \% \\
& \text { Tahun } 2017=\frac{2.141 .303 .053}{3.992 .436 .825} \times 100 \%=53,63 \% \\
& \text { Tahun } 2018=\frac{4.527 .984 .006}{6.438 .729 .971} \times 100 \%=70,32 \%
\end{aligned}
$$


Tabel 6: Perhitungan Efisiensi Anggaran Belanja

\begin{tabular}{ccccc}
\hline Tahun & $\begin{array}{c}\text { Realisasi Belanja } \\
\text { Langsung (Rp) }\end{array}$ & $\begin{array}{c}\text { Realisasi Anggaran } \\
\text { Belanja (Rp) }\end{array}$ & $\begin{array}{c}\text { Prosentase } \\
(\%)\end{array}$ & Kriteria \\
\hline 2016 & 2.238 .037 .764 & 3.378 .167 .944 & 66,25 & Efisien \\
\hline 2017 & 2.141 .303 .053 & 3.992 .436 .825 & 53,63 & Sangat Efisien \\
\hline 2018 & 4.527 .984 .006 & 6.438 .729 .971 & 70,32 & Efisien \\
\hline
\end{tabular}

Sumber: Data Diolah

Berdasarkan perhitungan dan tabel 6 diatas menunjukkan bahwa Badan Kesbangpol memiliki tingkat efisiensi yang cukup bagus dari tahun 2016 sampai 2018 dalam hal alokasi anggaran. Bahkan di tahun 2017 mengalami peningkatan menjadi sangat efisien. Hal ini menunjukkan bahwa Badan Kesbangpol mampu memaksimalkan anggaran yang tersedia untuk melakukan kegiatan belanja. Sehingga output yang dihasilkan sudah sesuai dengan apa yang seharusnya ingin dicapai.

\section{Efektivitas Anggaran Belanja}

Berdasarkan perhitungan tentang efektivitas anggaran belanja Badan Kesbangpol (lihat tabel 5) terlihat bahwa dari tahun 2016 sampai 2018 menunjukkan hasil dibawah 90\% yang masuk dalam katagori cukup efektif. Ketidak tercapainya realisasi anggaran atas rencana anggaran menjadi faktor penyebab utama. Anggaran belanja yang sudah direncanakan tidak dapat dilaksanakan dengan semestinya. Hal ini disebabkan karena proses perumusan anggaran belanja tidak dibahas dengan matang. Koordinasi antar lini juga menjadi faktor penyebab yang lain. Bisa jadi anggaran yang dipakai selama bertahun-tahun ini merupakan proses anggaran yang dilakukan secara berulang-ulang. Sehingga anggaran tersebut tidak mencerminkan program kerja yang nyata bagi Badan Kesbangpol yang menyebabkan proses penyerapan anggaran belanja menjadi tidak bisa maksimal.

\section{Efisiensi Anggaran Belanja}

Berdasarkan perhitungan tentang efisiensi anggaran belanja Badan Kesbangpol (lihat tabel 6) terlihat bahwa selama tiga tahun yakni dari tahun 2016 sampai 2018 menunjukkan hasil yang tergolong efisien. Bahkan ditahun 2017 mengalami kenaikan dan masuk kedalam katagori sangat efisien. Hal ini menunjukkan bahwa sebagian besar sumber dana yang dimiliki oleh Badan Kesbangpol mampu diwujudkan dan digunakan untuk kepentingan belanja organisasi. Dana yang berasal dari anggaran belanja tersebut mampu dioptimalkan dengan baik untuk menghasilkan sesuatu yang pencapaiannya lebih tinggi dari yang diharapkan sebelumnya. Badan Kesbangpol lebih cenderung menggunakan anggaran belanja tersebut untuk melakukan kegiatan belanja yang masuk dalam katagori langsung. Sebagai contoh probabilitas penggunaan anggaran tersebut untuk kegiatan belanja pegawai maupun belanja barang dan jasa yang sangat erat kaitannya dengan pelaksanaan suatu kegiatan atau program. Oleh karena itu penggunaan dana untuk kegiatan belanja langsung dapat menunjukkan bahwa kegiatan atau program tersebut telah dilakukan sesuai dengan rencana awal. 


\section{KESIMPULAN}

Berdasarkan hasil dan diskusi di atas maka dapat disimpulkan bahwa Badan Kesbangpol memiliki tingkat efektivitas yang tergolong menengah yakni di angka 80\% dan masuk kedalam kategori cukup efektif. Hal ini menunjukkan bahwa antara realisasi anggaran dengan target anggaran yang sudah ditetapkan di awal belum sepenuhnya berjalan dengan baik. Program-program yang belum berjalan menjadi faktor utama dari belum efektifnya penyerapan anggaran pada organisasi tersebut. Berbanding terbalik dengan tingkat efisiensi Badan Kesbangpol yang tergolong tinggi yakni masuk kedalam katagori efisien dan sangat efisien. Hal ini menunjukkan bahwa Badan Kesbangpol lebih mendahulukan program-program inti atau program-program yang menjadi tujuan utama dari organisasi tersebut sehingga penyerapan anggaran tersebut menjadi tepat sasaran dan sesuai dengan ouput yang diharapkan.

Hasil dari penelitian ini mempunyai implikasi kepada Badan Kesbangpol bahwa proses evaluasi kinerja harus tetap dilakukan terutama dalam hal penyerapan anggaran. Hal ini disebabkan karena salah satu indikator dari penilaian kinerja suatu organisasi publik adalah daya serap terhadap suatu anggaran yang mencerminkan terselenggaranya suatu program atau kegiatan dari organisasi tersebut. Sehingga saran yang dapat diberikan kepada organisasi tersebut adalah melakukan koordinasi antar bagian atau divisi dalam hal perumusan dan pembuatan anggaran belanja. Proses pembahasan juga menjadi poin penting dikarenakan anggaran belanja otomatis akan mengikuti juga dengan program yang dijalankan. Penyerapan anggaran akan lebih maksimal jika program yang terealisasi sesuai dengan program yang sudah dirancang.

Selain itu saran bagi peneliti selanjutnya adalah perlu memperluas topik penelitian. Sebagai contoh perbandingan antara anggaran pendapatan dengan anggaran belanja. Efektivitas dan efisiensi dapat ditentukan dengan memperhatikan dua aspek tersebut. Sehingga hasil dari penelitian tersebut menjadi komprehensif.

\section{ACKNOWLEDGEMENTS}

Penulis berterima kasih kepada D3 Akuntansi Universitas Islam Indonesia yang sudah mendukung baik moril dan meteril sehingga penelitian ini bisa dilakukan dengan lancar. Selain itu kepada Badan Kesatuan Bangsa dan Politik Kabupaten Sleman yang sudah memfasilitasi dan juga menjadi partner dalam melakukan penelitian ini.

\section{DAFTAR PUSTAKA}

Dwiyanto. A. (2005). Mewujudkan Good Covernance Melalui Pelayanan Publik. Yogyakarta: Gadjah Mada University Press.

Halim, A. (2014). Manajemen Keuangan Sektor Publik Problematika Penerimaan dan Pengeluaran Pemerintah. Jakarta: Salemba Empat.

Harly, K., \& Afriyenti, M. (2017). Analisis Kinerja Pemerintah Daerah Berdasarkan Informasi Finansial dan Informasi Non-Financial Pada Kota Solok (Studi Empiris Pada Pemerintah Daerah Kota Solok Tahun 2014- 
2016. Jurnal Wahana Riset Akuntansi, 5(2), 1063-1072.

Julita. (2011). Analisis Efektifitas dan Efisiensi Anggaran Pendapatan dan Belanja Pada Badan Lingkungan Hidup Provinsi Sumatera Utara. Kumpulan Jurnal Dosen Universitas Muhammasiyah Sumatera Utara, 10(2), 1-8. Keputusan Menteri Dalam Negeri Nomor 690.900-327 Tahun 1996 Tentang Pedoman Penilaian Kinerja Keuangan.

Mahsun, M. (2009). Pengukuran Kinerja Sektor Publik Edisi Ketiga. Yogyakarta: BPFE.

Mardiasmo. (2018). Akuntansi Sektor Publik. Yogyakarta: Andi Publisher.

Monoarfa, H. (2012). Efektivitas dan Efisiensi Penyelenggaraan Pelayanan Publik: Suatu Tinjauan Kinerja Lembaga pemerintahan. Jurnal Pelangi Ilmu, 5(1), 21-29.

Mulyadi. (2016). Sistem Akuntansi Edisi Keempat. Jakarta: Salemba Empat.

Nordiawan, D., \& Hertianti, A. (2010). Akuntansi Sektor Publik Edisi Kedua. Jakarta: Salemba Empat.

Peraturan Menteri Dalam Negeri Nomor 13 Tahun 2006 Tentang Pedoman Pengelolaan Keuangan Daerah.

Sudasri, D. (2016). Pengaruh Perencanaan Anggaran dan Kompetensi Sumber Daya Manusia Terhadap Penyerapan Anggaran (Studi Empiris pada SKPD Kota Padang). Skripsi, Universitas Negeri Padang, Padang.

Sugiyono. (2015). Metode Penelitian Kombinasi (Mix Methods). Bandung: Alfabeta.

Syamsi, S. (2014). Partisipasi Masyarakat Dalam Mengontrol Penggunaan Anggaran Dana Desa. Jurnal IImu Sosial dan Ilmu Politik, 3(1), 21-28.

Tamasoleng, A. (2015). Analisa Efektifitas Pengelolaan Anggaran di kabupaten Kepulauan Siau Tagulandang Biaro. Jurnal Riset Bisnis dan Manajemen, 3(1), 97-110.

Undang-undang Nomor 15 Tahun 2004 Tentang Pemeriksaan Pengelolaan dan Tanggung Jawab Keuangan Negara. 